\title{
Study on Diagnostic Evaluation of Pancytopenic Patients
}

\author{
Md. Rezaul Karim Chowdhury *1, Md. Haroon ur Rashid ${ }^{2}$, Amina Begum ${ }^{3}$, \\ Shamimur Rahman ${ }^{4}$, Md. Momenuzzaman Khan ${ }^{5}$
}

Abstract

Introduction: Pancytopenia is a common hematological problem with an extensive differential diagnosis and is a challenging problem to the treating physician. Bone marrow aspiration and biopsy is an important diagnostic test for patient management. The objective of this study is to find out the incidence various causes of pancytopenia in patients attending to the Enam medical college hospital in savar. Materials and Methods: This prospective observational study was done in the department of haematology, Enam Medical College Hospital (EMCH) from July 2012 to June 2019. Results: In our study out of 66 patients, 36 (54.55\%) were male, 30 (45.45\%) were female and male to female ratio were 1.2:1. Generalized weakness $47(71.21 \%)$ and fever $23(34.85 \%)$ were the most common presenting symptoms followed by bleeding $17(25.76 \%)$, weight loss $6(12.12 \%)$, bodyache $6(9.09 \%)$. Most common clinical findings were anemia 57 $(86.36 \%)$ and bone tenderness $22(33.33 \%)$. Other physical findings were purpura/brusing 13 (19.70\%), splenomegaly 10 (15.15\%), lymphadenopathy $4(6.06 \%)$ and hepatomegaly $3(4.55 \%)$. Hematological malignancy 29 (43.94\%) and hypoplastic marrow $26(39.39 \%)$ were the most common bone marrow finding of pancytopenic patients followed by megaloblastic anaemia $4(6.06 \%)$, leishmaniasias 5 (7.58), and erythroid hyperplasia 2 (3.03\%). Acute myeloid leukaemia was the common haematological malignancy 16 (24.24\%), others were acute lymphoblastic leukaemia 5 (7.58\%). Myelodysplastic syndrome 3 (4.55\%), multiple myeloma 4 (6.06\%), chronic myelogenous leukaemia in blastic crisis $1(1.52 \%)$. Conclusion: So we concluded that complete workup is essential for all cases of pancytopenia to find out the treatable cases and to reduce the motality and morbidity in serious diseases.

Key words: Pancytopenia, Bone marrow examination, Haematological malignancy.

Number of Tables: 02; Number of References: 39; Number of Correspondesce: 03.

*1. Corresponding Author:

Dr. Md. Rezaul Karim Chowdhury

MBBS, MD, D-Card

Associate Professor

Department of Haematology

Enam Medical College \& Hospital, Savar.

Email: rkchow71@gmail.com

Mobile: 01712141988

2. Dr. Md. Haroon ur Rashid

MBBS, MD

Associate Professor

Department of Pulmonology

Enam Medical College \& Hospital, Savar.

3. Dr. Amina Begum, MBBS, MD

Medical Officer, Department of Physiology

Bangabandhu Sheikh Mujib Medical University

(BSMMU), Dhaka.

4. Dr. Shamimur Rahman

Associate Professor

Department of Nephrology

Enam Medical College \& Hospital, Savar.

5. Dr. Md. Momenuzzaman Khan

Associate Professor

Department of Neurology

Enam Medical College \& Hospital, Savar.

\section{Introduction:}

Pancytopenia is a common hematological problem with an extensive differential diagnosis and is a challenging problem to the treating physician. It is not a disease but a triad of anaemia, leucopenia and thrombocytopenia. Various pathophysiological mechanisms are related to the development of pancytopenia and this includes reduced or ineffective hematopoiesis and increased destruction by either sequestration or destruction by antibodies ${ }^{1}$. The cause of pancytopenia may be thus lie in the bone marrow, periphery or both. Various factors encompassing geographic distribution and genetic disturbances may cause variation in the incidence of disorders causing pancytopenia ${ }^{2,3,4}$. The presenting symptoms are often attributed to anaemia/ thrombocytopenia. Leukopenia is an uncommon cause of initial presentation but can become the most serious threat to life during the course of the disorder ${ }^{5}$. A detailed history, physical examination and complete blood counts with reticulocyte count and peripheral blood smear remain essential for diagnosis. Bone marrow examination is essential to determine the cause of pancytopenia, as it plays a major role in hematological malignancies, unexplained cytopenias and storage disorders ${ }^{6}$. Trephine biopsy is mainly undertaken when hypoplasia or aplasia of bone marrow being suspected on aspiration ${ }^{7}$. The severity of pancytopenia and the underlying pathology determine the management and prognosis of these patients ${ }^{8}$. The objective of this study is to find out the incidence various causes of pancytopenia in patients attending to Enam medical college hospital in savar.

\section{Materials and Methods:}

This prospective observational study was done in the department of haematology, Enam Medical College Hospital (EMCH) from July 
2012 to June 2019. A total of 66 pancytopenic patient were included in this study. Chemotherapy, radiotherapy and drug induced pancytopenia cases were excluded. Pancytopenia was confirmed by complete blood count and peripheral smear examination. Clinical parameters were assessed, and other necessary haematological investigations were done. Bone marrow aspiration was done thereafter. When aspirated material was inadequate or there was dry tap, trephine biopsy was done. Data was collected and subsequently analyzed.

\section{Results:}

Total 66 patients were included in our study. 36 (54.55\%) were male, $30(45.45 \%)$ were female and male to female ratio were 1.2:1. The age range of the patients were 9 years to 80 years. Generalized weakness $47(71.21 \%)$ and fever $23(34.85 \%)$ were the most common presenting symptoms. Other presenting symptoms were bleeding 17 (25.76\%), weight loss 6 (12.12\%), Bodyache 6 (9.09\%). Most common clinical findings were anemia 57 (86.36\%) and bone tenderness $22(33.33 \%)$. Other findings were purpura/brusing $13(19.70 \%)$, splenomegaly $10(15.15 \%)$, lymphadenopathy $4(6.06 \%)$ and hepatomegaly $3(4.55 \%)$.

Haematological malignancy 29 (43.94\%) and hypoplastic marrow $26(39.39 \%)$ were the most common bone marrow finding of pancytopenic patients. Bone marrow finding are given in table I.

Table-I: Bone marrow aspiration finding in case of pancytopenia :

\begin{tabular}{lcc}
\hline Bone marrow finding & No.of cases & Percentage(\%) \\
\hline Haematological malignancy & 29 & 43.94 \\
Hypoplastic bone marrow & 26 & 39.39 \\
Leishmaniasis & 5 & 7.58 \\
Megaloblastic anemia & 4 & 6.06 \\
Erythroid hyperplasia & 2 & 3.03 \\
\hline
\end{tabular}

Most common haematological malignancy was acute myeloid leukaemia 16 (55.17\%). Haematological malignancies are summarizing in table II.

Table-II: Haematological malignancies:

\begin{tabular}{lllll}
\hline Haematological malignancies & $\begin{array}{l}\text { No of cases } \\
(\mathrm{n}-29)\end{array}$ & $\begin{array}{l}\text { Percentage } \\
\text { (\%) }\end{array}$ & $\begin{array}{l}\text { Total number } \\
\text { of cases (n-66) }\end{array}$ & $\begin{array}{l}\text { Percentage } \\
\text { (\%) }\end{array}$ \\
\hline Acute myeloid leukaemia & $16 / 29$ & 55.17 & $16 / 66$ & $24.24 \%$ \\
$\begin{array}{l}\text { Acute lymphoblastic } \\
\text { leukaemia }\end{array}$ & $5 / 29$ & 17.24 & $5 / 66$ & $7.58 \%$ \\
Multiple myeloma & $4 / 29$ & 13.79 & $4 / 66$ & $6.06 \%$ \\
$\begin{array}{l}\text { Myelodysplastic syndrome } \\
\text { Chronic myelogenous }\end{array}$ & $3 / 29$ & 10.34 & $3 / 66$ & $4.55 \%$ \\
leukaemia in blastic crisis & $1 / 29$ & 3.45 & $1 / 66$ & $1.52 \%$ \\
\hline
\end{tabular}

\section{Discussion:}

Pancytopenia is quite common in our day today clinical practice and challenging problem to both physicians and haematologists. Patients commonly presents with features of varying degrees of anaemia followed by infections and bleeding manifestations. A wide variety of disorder can causes pancytopenia demanding thorough evaluation. Diagnostic tools of pancytopenic patients are peripheral blood smear examination, bone marrow aspirations and trephine biopsy.
Total 66 patients with pancytopenia were included in our study with male preponderance, $36(54.55 \%)$ patients were male, $30(45.45 \%)$ were female and male: female ratio was 1.2:1. This is in agreement with Parmar JK et al.(1.6: 1), Nigam RK et al. (1.12: 1), Thakkar BB et al. (1.08:1), Para R \& Para S. (1.1: 1), Goyal $H$ et al, (1.37:1) studies $^{9,10,11,12,13}$. The exact cause of male preponderance is unknown, but may be partly explained by increased exposure of male to environmental agents like agricultural pesticide. Few studies showed female preponderance ${ }^{14,15}$. Age range was 9 years to 80 years in our study. Same age group also seen by Tilak $\mathrm{V}$ and Jain $\mathrm{R}^{8}$, Tariq $\mathrm{M}$ et al., ${ }^{16}$ Mussarrat $\mathrm{N}$ et al., ${ }^{17}$ Qamar U and Aijaz J. ${ }^{18}$ Khodke K et al., ${ }^{19}$ and Gayathri BN and Rao KS. ${ }^{20}$ of their studies.

Generalized weakness 47(71.21\%) and fever 23(34.85\%) were the most common presenting symptoms. Other presenting symptoms were bleeding 17 (25.76\%), weight loss $6(12.12 \%)$, body ache $6(9.09 \%)$. Generalized weakness and fever also a most common presenting symptoms were seen in Niazi $\mathrm{M}$ and Raziq F. ${ }^{21}$ Pathak R et al. ${ }^{22}$ Kumar DB, Raghupathi AR ${ }^{14}$. Most common clinical findings were pallor $57(86.36 \%)$ and bone tenderness $22(33.33 \%)$. Pallor was the common clinical sign seen by Parmar JK et al (100\%), Thakkar B B et al. (100\%), Goyal $\mathrm{H}$ et al. (97.8\%), Chhabra A et al.(64.8\%) ${ }^{9,11,13,23}$. The 2 nd most common clinical finding was bony tenderness $(33.33 \%)$ which was near similar to Hayat AS et al. study $(44.70 \%)^{24}$ but lower than Anita PJ et al. study(4.71\%) ${ }^{25}$. Other findings in our study were purpura/brusing $13(19.70 \%)$, splenomegaly $10(15.15 \%)$, lymphadenopathy $4(6.06 \%)$ and hepatomegaly $3(4.55 \%)$. Common Physical findings included hepatomegaly $(24.52 \%)$, Splenomegaly $(17.92 \%)$ and lymphadenopathy (5.66\%) in Anita PJ et al. study $^{25}$, and hepatomegaly $(24.32 \%)$, splenomegaly (44.14\%) and lymphadenopathy (6.31\%) in Santra G et al. study $^{26}$. The frequencies of other clinical features were variable and different from these studies probably due to broad spectrum of etiologies behind pancytopenia.

Hematological malignancy $29(43.94 \%)$ was the most common bone marrow finding of pancytopenic patients in our study which was similar to Imbert $\mathrm{M}$ et al. ${ }^{29}$ study. The commonest cause of pancytopenia was aplastic anemia reported by Mussarrat $\mathrm{N}$ et al. $(38.3 \%)^{17}$, Qamar U and Aijaz J. $(50.67 \%)^{18}$, Khodke K et al. $(29.5 \%)^{19}$, Lakhey A et al $(29.6 \%)^{27}$, Hossain MA et al. ${ }^{28}$, whereas in our study it is second common cause accounting for $39.39 \%$ (n-26).

The commonest cause of pancytopenia was megaloblastic anaemia reported by Rahim F et al. $(24.92 \%)^{7}$, Javalgi AP and Dombale VD. $(72.6 \%)^{30}$, Rangaswamy $\mathrm{M}$ et al.(49\%) ${ }^{31}$, whereas in our study it was $6.06 \%(n-4)$. We avoided bone marrow examination in suspected cases of megaloblastic anaemia because it is not an essential test for diagnosis.

In our study leishmaniasis seen in $7.58 \%(n-5)$ and erythroid hyperplasia seen in 3.03\% (n-2) cases. Leishmaniasis $2.1 \%, 6.9 \%, 0.6 \%$ was seen in Goyal $\mathrm{H}$ et al. ${ }^{13}$, Mallik $\mathrm{M}$ et al. ${ }^{32}$, Ojah S et al. ${ }^{33}$ study. Erythroid hyperplasia $11.11 \%$, $3 \%, 11.3 \%$ was seen in, Lakhey A et al. ${ }^{27}$, Sakunthala and Subitha S.34 Makheja KD et al. ${ }^{35}$ study. 
In our study, 43.94\% (n-29) of patients presented with haematological malignancy with pancytopenia and was the most common cause of pancytopenia. In present study acute myeloid leukaemia was $24.24 \%$ ( $n-16)$ of our total cases whereas Jha A et al. ${ }^{36}$ found acute myeloid leukaemia to be $19.59 \%$ of total cases. Lakhey a et al. ${ }^{27}$ found $12.96 \%$ of total cases in their study. Savage DG et al. ${ }^{37}$ in Zimbabwe and Varma $\mathrm{N}$ et al. ${ }^{38}$ also described acute myeloid leukaemia as the third most common cause of pancytopenia.

In this study acute lymphoblastic leukaemia comprised of $7.58 \%$ (n-5) of our pancytopenic patients. In other studies showed $3.70 \%$ and $10 \%$ of their total cases ${ }^{27,39}$.

Pancytopenia with multiple myeloma as diagnosis was noted in $6.06 \%$ (n-4) of our total patient compared to Khodke $\mathrm{K}$ et al. where it was reported to be $4 \%$.

Out of 66 cases the incidence of myelodysplastic syndrome in our study constituted 4.55\% (n-4). Qamar U and Aijaz $\mathrm{J} .{ }^{18}$ reported $5.3 \%$ which is comparable to our study. Other study were showed $8.3 \%, 2.4 \%, 7.4 \%{ }^{14,17,27}$.

We observed that causes of pancytopenia were variable and different from study to study. This is due to the differences in methodology and stringency of diagnostic criteria, geographic area, period of observation, genetic differences and varying exposure to toxic agents etc.

\section{Conclusion:}

Pnacytopenia is a common entity in our clinical practice. Bone marrow aspiration and biopsy is an important diagnostic test for patient management. Hypoplastic bone marrow, haematological malignancy and megaloblastic anaemia are the most common cause's pancytopenia. In our study common causes are haematological malignancy and hypoplastic marrow. However, uncommon and rare causes such as myelofibrosis, hairy cell leukaemia, storage disease and infection etc should be kept in mind during complete work up.

\section{Conflict of Interest: None.}

\section{Acknowledgment:}

We acknowledgment the help of the staff of department of haematology for their unstinted support and cooperation.

\section{References:}

1.Williams MD. Pancytopenia, aplastic anemia and pure red cell aplasia. In: Lee RG, Foerster J, Lukens J, Paraskevas F, Greer JP, Rodgers GM, (eds). Wintrobe's Clinical Haematology. 10th edn. Williams and Wilkins ;1997: 1449-1476.

2. International agranulocytosis and aplastic anemia study. Incidence of Aplastic anemia, relevance of diagnostic criteria. Blood. 1987; 70: 1718-1721.

https://doi.org/10.1182/blood.V70.6.1718.bloodjournal7061718

https://doi.org/10.1182/blood.V70.6.1718.1718

3. Wintrobe MM (ed). Clinical Hematology. 8th edition. Philadelphia: Lea and Febiger; 1981: 699-915.
4. Keiser M, Ost A. Diagnosis in patients with severe pancytopenia suspected of having aplastic anemia. EurJ Haematol. 1990; 45:11-14.

https://doi.org/10.1111/j.1600-0609.1990.tb00407.x PMid:2379559

5. Firkin F, Chesterman C, Pennigton D, Rush B. De Gruchy's Clinical Hematology in Medical Practice. 5th ed. London: Blackwell Science Ltd; 1989: 119-136.

6. Iqbal W, Hassan K, Ikram N, Nur S. Aetiological Breakup in 208 Cases of Pancytopenia. J Rawal Med Coll. 2001; 5(1): 7-10.

7. Rahim F, Ahmad I, Islam S, Hussain M, Khattak TAK, Bano Q. Spectrum of hematological disorders in children observed in 424 consecutive bone marrow aspirations/biopsies. Pak J Med Sci. 2005; 21: 433-436.

8.Tilak V, Jain R. Pancytopenia - A Clinico hematologic analysis of 77 cases. Indian J Pathol Microbiol. 1999; 42(4): 399-404.

9. Parmar JK, Sheikh S, Vidja P. Etiological evaluation of Pancytopenia with special emphasis on megaloblastic anemia, Paripex, Indian journal of

Research. 2013; 3(4): 263-264.

10. Nigam RK, Chaudhary R, Malik R, Gour D, Shrivastava A, Tripathi A, et al. Pancytopenia- clinico-haematological studies of bone marrow examination. Journal of Evolution of Medical and Dental Sciences. 2013; 2(7): 9213-9219.

https://doi.org/10.14260/jemds/1598

11. Thakkar B B, Bhavsar N Ukti, Trivedi N J, Agnihotri AS. A study of pancytopenia in adult patients more than 12 years of age in north west region of saurashtra. National Journal of medical research. 2013; 3(1): 48-52.

12. Para R, Para S. Pancytopenia - a study of 58 cases. Journal of Evolution of Medical and Dental Sciences. 2013; 2(45): 8724-8728.

https://doi.org/10.14260/jemds/1513

13. Goyal H ,Tilak V \& Singhal A. Clinico-Hematological Study of Pancytopenia with Special Reference to Idiopathic Pancytopenia. Global Journal of Medical Research. 2017; 17(1): 8-17.

14. Kumar DB, Raghupathi AR. Clinicohematologic analysis of pancytopenia study in a tertiary care centre. Basic and Applied Pathology. 2012; 5: 19-21.

https://doi.org/10.1111/j.1755-9294.2011.01121.x

15. Yadav S, Kushwaha R, Aggrawal K,Tripathi AK, Singh US, Kumar AK. A Clinico- hematological study in cases of pancytopenia: correlation of automated cell counter parameters in various etiologies. Journal of Evolution of Medical and Dental Sciences. 2013; 2(22): 4013-4023.

https://doi.org/10.14260/jemds/795 
16. Tariq M, Khan N, Basri R, Amin S. Aetiology of pancytopenia. Prof Med J. 2010; 17: 252-256.

17. Mussarrat N, Fazal-e-R M, Mohammad TK. Clinical and hematological features of megaloblastic anemia alone or in combination with iron deficiency anemia - An analysis of 349 patients. J Med Sci. 2009; 17: 81-84.

18. Qamar U, Aijaz J. Results of bone marrow examination in patients presenting with pancytopenia and high mean corpuscular volume. Gomal J Med Sci. 2012;10:133-136.

19. Khodke K, Marwah S, Buxi G, Yadav RB, Chaturvedi NK. Bone marrow examination in cases of pancytopenia. J Indian Acad Clin Med. 2001; 2:56-59.

20. Gayathri BN, Rao KS. Pancytopenia: A clinico hematological study. J Lab Physicians. 2011; 3:15-20.

https://doi.org/10.4103/0974-2727.78555

PMid:21701657 PMCid:PMC3118050

21. Niazi M, Raziq F. The incidence of underlying pathology in pancytopenia: an experience of 89 cases. J Postgrad Med Inst. 2004; 18:76-79.

22. Pathak R, Jha A, Sayami G. Evaluation of bone marrow in patients with pancytopenia.J Pathology Nepal. 2012; 2: 265-271.

https://doi.org/10.3126/jpn.v2i4.6875

23. Chhabra A, Chandar V, Patel A, Chandra H. Clinicoaetiological profile of pancytopenia in paediatric practice Journal. Indian Academy of Clinical Medicine. 2012;13(4): 282-285

24. Hayat AS, Khan AH, Baloch GH, Shaikh N. Pancytopenia; study for clinical features and etiological pattern of at tertiary care settings in Abbottabad. Professional Med J. 2014; 21(1): 60-65.

25. Anita PJ, Vijay DD. Clinico - Hematological Analysis of Pancytopenia: A Bone Marrow Study. National Journal of Laboratory Medicine. 2013; 2(4): 12-17.

26. Santra G, Das BK. A cross sectional study of the clinical profile and aetiological spectrum of pancytopenia in a tertiary care center. Singapore Med J. 2010; 51(10): 806-812.

27. Lakhey A, Talwar OP, Singh VK, Raj SK. Clinico-hematological study of pancytopenia. J Pathol Nepal. 2012; 2:207-210

https://doi.org/10.3126/jpn.v2i3.6023

28. Hossain MA, Akond AK, Chowdhary MK, Singh KJ, Ahluwalia G, Sharma SK, et al. Pancytopenia - A study of 50 cases. Bangladesh J Pathol.1992; 1: 9-12.
29. Imbert M, Scoazec JY, Mary JY, Jouzult H, Rochant H, Sultan C. Adult patients presenting with pancytopenia: A reappraisal of underlying pathology and diagnostic procedures in 213 cases. Hematol Pathol.1989; 3: 159-167.

30. Javalgi AP, Dombale VD. Bone marrow study in pancytopenia. Natl J Lab Med. 2013; 2: 12-17.

31. Rangaswamy M, Prabhu, Nandini NM, Manjunath GV. Bone marrow examination in pancytopenia. J Indian Med Assoc. 2012; 110: 560-566.

32. Mallik M, Bhartiya R, Mallick S, Singh R, Kumar M, Singh RVN. Pancytopenia - A study of Clinico-Haematological Profile in Adults with its Bone-Marrow Co-Relation in a Tertiary Hospital of Bihar. International Journal of Contemporary Medical Research. 2016; 3(6): 1689-1691.

33. Ojha S, Haritwal A, Meenai FJ, Gupta S. Bone marrow examination findings in cases of pancytopenia- a study from central India. Indian Journal of Pathology and Oncology. 2016; 3(3): 479-484

https://doi.org/10.5958/2394-6792.2016.00089.2

34. Sakunthala and Subitha S. Bone Marrow Examination In Cases Of Pancytopenia. IOSR-JDMS. 2018; 17(5): 75-78.

35. Makheja KD, Maheshwari BK, Arain S, Kumar S, Kumari S, Vikash. The common causes leading to pancytopenia in patients presenting to tertiary care hospital.Pak J Med Sci. 2013; 29( 5): 1108-1111.

https://doi.org/10.12669/pjms.295.3458

36. Jha A, Sayami G, Adhikari RC, Patna AD, Jha R. Bone marrow examination in cases of pancytopenia. J Nepal Med Assoc. 2008; 47: 12-17

https://doi.org/10.31729/jnma.209

37. Savage DG, Allen RH, Gangaidzo IT. Pancytopenia in Zimbabwe. Am J Med Sci.1999; 317: 22-32.

https://doi.org/10.1016/S0002-9629(15)40466-5

https://doi.org/10.1097/00000441-199901000-00004

PMid:9892268

38. Varma N, Dash S. A reappraisal of underlying pathology in adult patients presenting with pancytopenia. Trop GeogrMed. 1992; 44: 322-327.

39. Sreeramulu D, Laxmibai S, Srinivasulu D, Malik M S. Pancytopenia-An Evaluation. International Journal of Applied Research. 2015; 1(10): 744-746. 